\title{
膝蓋腱断裂に人工勒带を使用した治療経験
}

\author{
宮崎社会保険病院整形外科 \\ 小 薗 敬 洋・松 元 征 徳 \\ 森治 樹・田邊 龍 樹 \\ タヅメクリニック
}

田爪陽一郎

宮崎医科大学整形外科

増田寛

\section{Clinical Experience of Patellar Tendon Rupture \\ Using Artificial Ligament}

\author{
Takahiro Kozono, Masanori Matsumoto, Haruki Mori, \\ and Ryuji Tabe \\ Department of Orthopaedic Surgery, \\ Miyazaki Social Insurance Hospital, Miyazaki, Japan \\ Yoichiro Tazume \\ Tazume Clinic, Miyazaki, Japan \\ Hiroshi Masuda \\ Department of Orthopaedic Surgery, \\ Miyazaki Medical Collage, Miyazaki, Japan
}

\begin{abstract}
Patellar tendon rupture rarely occurs in adults without systemic diseases. We report two cases of fresh patellar tendon rupture treated with augmentation using the LeedsKeio artificial ligament. The remnants of the ruptured tendon were preserved. The artificial ligament was passed transversely through the distal end of the quadriceps tendon along the proximal margin of the patella and it crossed itself in front of the patella in a cross shape. Both ends of the implant were passed through a transverse tunnel drilled through the tibial tuberosity. CPM exercise was begun on the second day after surgery. Active knee extension was permitted at three weeks postoperatively. The advantages of this method are there is no need for immobilization and that rehabilitation is much quicker.
\end{abstract}

Key words : patellar tendon rupture (膝蓋腱断裂), artificial ligament (人工勒帯), augmentation（補強）

\section{は じめに}

健常な膝蓋腱は極めて強勒であり, 膝の伸展機構の なかでも膝蓋骨に比べ損傷を受けにくく，断裂は稀で ある.これまでさまざまな治療方法が報告されている
が，その選択については未だ見解の一致が得られてい ない.今回われわれは膝蓋腱断裂の 2 例を経験し, Leeds-Keio 勒带を使用した再建術で良好な結果を得 たので，文献的考察を加えて報告する. 
方法

手術は，Leeds-Keio 勒帯を大腿四頭筋腱に冠状に 通し，膝蓋骨前面で 8 の字状に交差させて脛骨結節下 縁後方に骨孔を穿ち固定する方法 ${ }^{12) 4)}$ で行つた。膝蓋 腱の断端は pull out 法で膝蓋骨下極に縫合した。䊫 蓋骨前面で交差させた Leeds-Keio 勒帯（15mm 幅） を骨トンネルに通し，脛骨に double stapling 法によ り固定した（図 1).

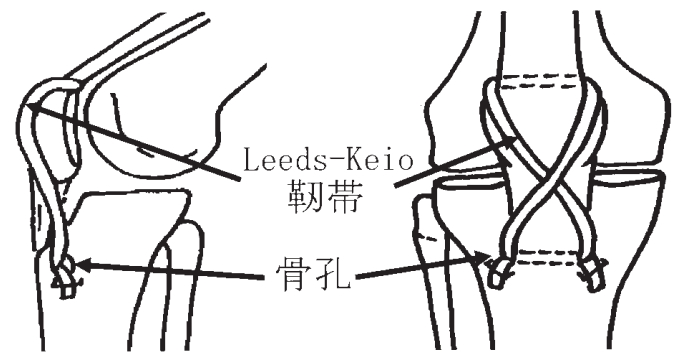

図 1 手術方法のシェーマ

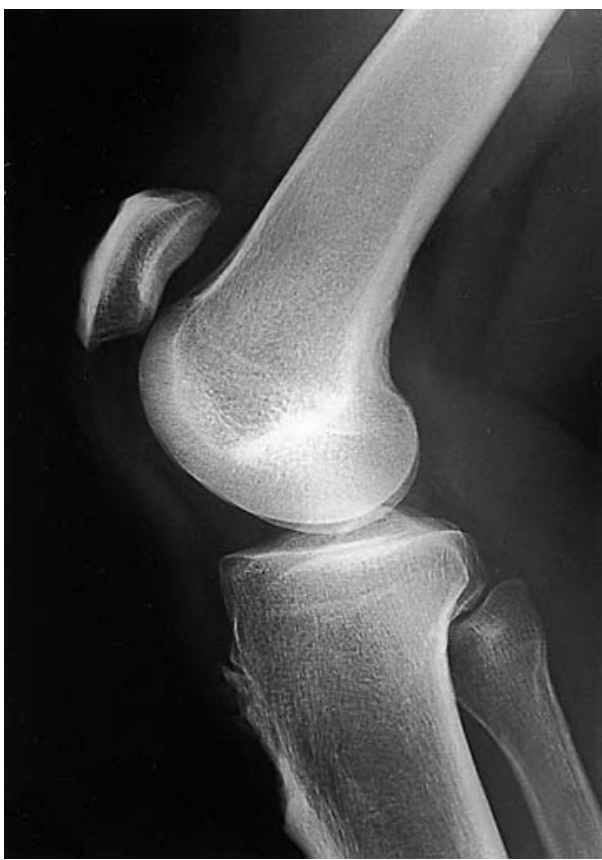

a. 単純 X 線側面像
固定する際に膝蓋骨の位置，腱の緊張度が重要とな るが，われわれは術前に撮影した健側膝蓋骨の高位 (0，30，60，90 度）を目安として，イメージ下に緊 張を加えながら整復位をとり固定した，その際，各可 動域での膝蓋腱縫合時の緊張度を肉眼で確認した.

後療法は, 術後 2 日目で CPM による可動域訓練を 開始し, 術後 2 週で他動運動開始した. 術後 4 週で部 分荷重歩行を行い, スポーツ復帰は 3 力月後からとし た.

$$
\text { 症例 }
$$

症例 1. 43 歳, 男性. 職業大工. 既往歴に特記事項 はない. 2002 年 3 月に足がもつれて転倒した際に左 膝を屈曲強制した．同部の疼痛と歩行困難を認め, 同 日当科を受診した. 初診時, 左膝に腫脹・圧痛があり, 近位に陥凹を触れ, 左膝関節自動伸展は不能であった. 単純 X 線像の正面・側面像で著明な膝蓋骨高位を呈 した. MRIでは膝蓋腱の明らかな断裂を認めた。受 傷 1 週間後に再建術を行った.

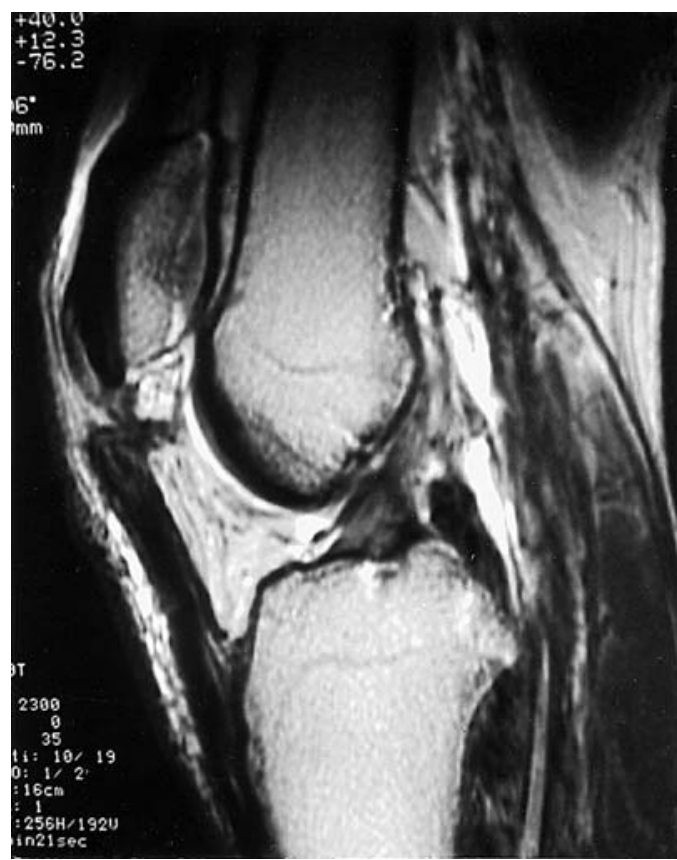

b. MRI T2 強調像

図 2 症例 2 . 入院時. a 著明な膝蓋骨高位を呈する. b 膝蓋骨下極で膝蓋腱の連続性が 途絶えている. 


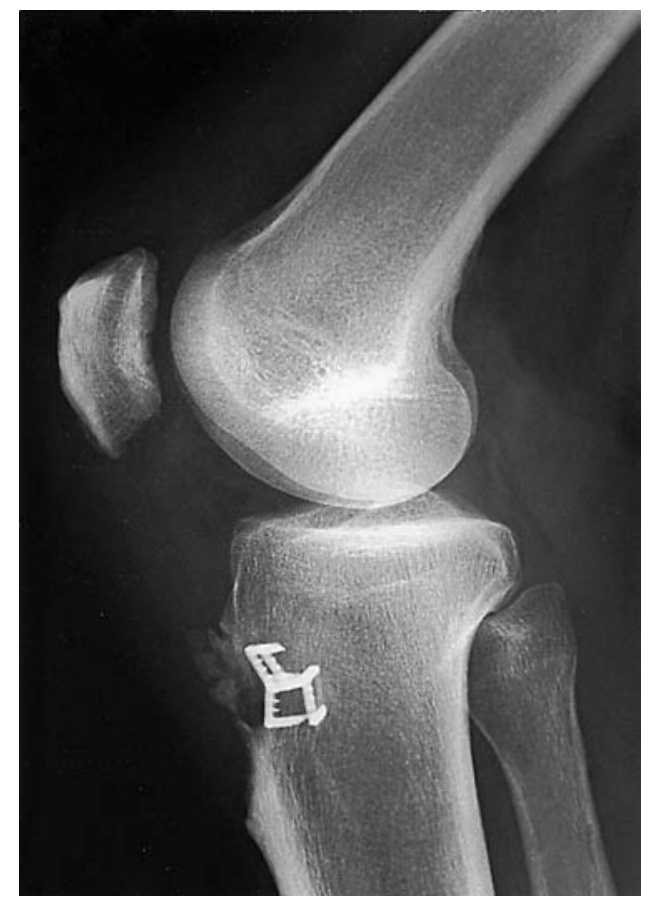

a. 単純 X 線側面像

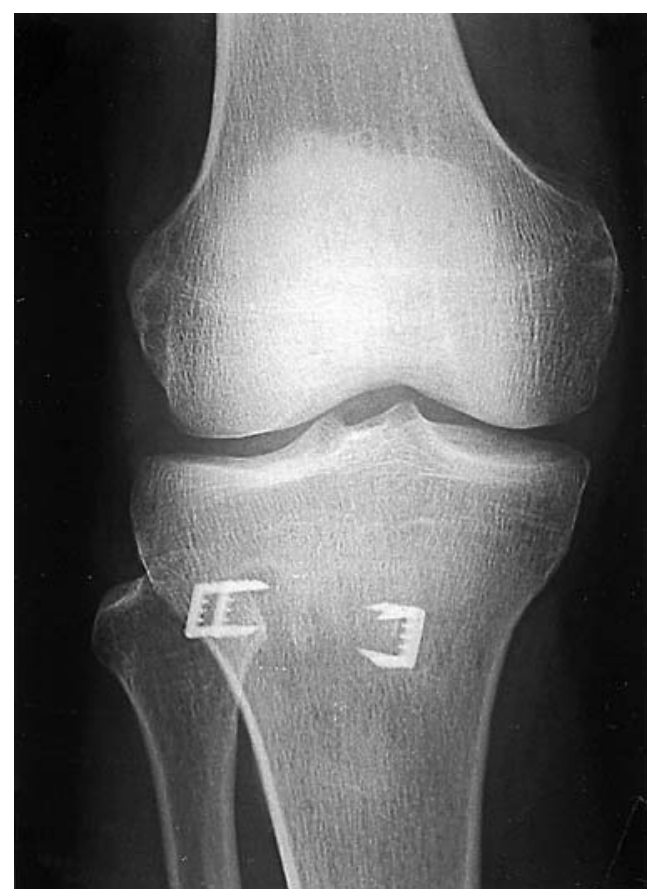

b. 正面像

図 3 症例 2. 術後 1 年経過時.

a, b 膝蓋骨は整復位に保たれている.

症例 2. 39 歳, 男性. 職業教師. 既往歴に特記事項 はない. 2002 年 2 月にバレーボールでジャンプした 際に受傷した．初診時，右膝蓋腱部に陥凹を触れ，右 膝関節自動伸展は不能であった。

単純 X 線像の側面像で著明な膝蓋骨高位を呈した. MRI では膝蓋骨下極で膝蓋腱の連続性が途絶えてい た（図 2)。受傷後 9 日目に再建術を行った.

$$
\text { 結果 }
$$

術後 1 年以上を経過し, 1 例に膝過屈曲位から伸展 動作開始の際に軽度の痛みの訴えがあるが，その他の 自覚症状は無く, 可動域制限もない.また大腿周径の 健側との優位な差を認めていない。単純 X 線像では 膝蓋骨の整復位は保たれている（図 3 ）。

考察

膝蓋腱断裂の治療は, 再建材料の選択, 緊張度の決 定，固定時の膝関節屈曲角度の決定，再建材料の固定
法など，いまだ見解の一致が得られていない。手術時 期に関しては, Sivekらは断裂後 2 週以内であれば修 復術の成績は良好であると報告 ${ }^{5}$ している。したがつ て可及的早期の修復術の施行が望ましいと考えられる.

新鮮例に対する治療法は, wiring 法 $^{3)}$ など一次修 復術が多く報告されている，基礎疾患に基づく場合， 一次修復では再断裂が危惧される場合など，ワイヤー・ 自家組織・人工䩲帯によって補強した報告がタられる. 陳旧例では，富士川ら¹)による一期的な再建法の報告 や，関節可動域と正常の膝蓋骨の位置を得たのちに， 二期的に再建術を行う方法が報告 ${ }^{5)}$ されている.

膝蓋腱の再建に際しては，それに耐えうる強力な勒 帯が形成される必要があり，また早期から可動域訓練 を開始するためには，術直後から十分な強度を有する ことが要求される ${ }^{6)}$. 術中には腱の緊張度の決定が重 要となる。これが強いと膝蓋骨低位を来し，大腿四頭 筋筋力は保持されるが膝屈曲制限, 膝蓋大腿関節障害 を来すことになる．また逆にこれが弱いと，膝蓋骨高 
位となり, 大腿四頭筋筋力の低下などの膝伸展制限を 来すことになる゙．そのためわれわれは術中 X 線コン トロールを行い, 腱の緊張度を確認した.

1984 年に松本ら ${ }^{4)}$ は Leeds-Keio 勒帯による膝蓋腱 再建術の 5 例を報告し, 強度, 組織誘導性, 手術の簡 便さを述べている。本法では勒帯の強度を自由に調整 し固定可能である. 今回われわれは術後 1 年の短期成 績であるが，本法を用いて良好な結果を得た．固定位 置の問題では, 膝蓋骨内を通さず, また応力の分散に より cheese cutting 現象を伴わない点, 8 の字の交 差部で膝蓋骨を押さえ，前方跳ね上がりを防止できる 点などでも優れている. さらに外固定が不要であり, 本症例のように術翌日からの可動域訓練など後療法の 早期開始が可能である.

\section{ま と め}

膝蓋腱断裂の 2 例を経験し Leeds-Keio 勒帯を用い た再建術を行い良好な結果を得た。

\section{参 考 文 献}

1) Fujikawa, K. et al.: Reconstruction of the extensor apparatus of the knee with the Leeds-Keio ligament. J. Bone Joint Surg., 76-B : 200-203, 1994

2）上村民子ほか：腎性骨異栄養症に発生した膝蓋断裂勒 带の 1 治療例. 整形外科, $46: 625-628,1995$.

3) McLaughlin, H. L.: Repair of major tendon rupture by buried removal suture. Am. J. Surg., 74 : 758-764, 1947.

4）松本秀男 : Leeds-Keio 人工勒带による膝蓋勒带再建術. 臨整外, $20: 977-983,1985$.

5) Siwek, C. W., Rao, J.P.: Rupture of the extensor mechanism of the knee joint. J. Bone Joint Surg., 63-A : 932-937, 1981.

6) 数面義雄ほか：Leeds-Keio 人工勒带による膝蓋勒带再 建術の 1 例. 整・災外, $35: 85-89,1992$. 